\title{
TINJAUAN HUKUM HUBUNGAN KEMITRAAN ANTARA EKSEKUTIF DAN LEGISLATIF DALAM PENYELENGGARAAN PEMERINTAHAN DAERAH
}

\author{
Nila Trisna \\ Fakultas Ilmu Sosial dan Ilmu Politik Universitas Teuku Umar \\ nilatrisna76@gmail.com
}

\begin{abstract}
The Regional People's Legislative Assembly (DPRD) is a form of representative institution of the people of provinces, districts, or cities in Indonesia which is located as an element of local government administration together with the Regional Government. The existence of the Regional People's Legislative Assembly is regulated, among others, in Law Number 27 Year 2009 concerning the People's Consultative Assembly, the People's Legislative Assembly, the Regional Representative Council, and the Regional People's Legislative Assembly. Article 342 of Law Number 27 Year 2009 stipulates that "Regency / Municipal DPRD shall be a regional representative body domiciled as the element of the regional administration of a regency / municipality. In formal juridical, DPRD is the working partner of Regional Head either Governor, Regent, or Mayor. Since the enactment of Law Number 32 Year 2004 regarding Regional Government, the Regional Head shall no longer be responsible to the Regional People's Legislative Assembly, since it shall be elected directly by the people through the election of the Regional Head and Deputy Regional Head. Article 27 Paragraph (2) of Law Number 32 Year 2004 stipulates, among other things, that "the Regional Head has an obligation also to provide reports on the implementation of regional government to the Government, and to give accountability report to the DPRD". Nevertheless, the role of DPRD is enormous in determining regional policy.This study uses the normative juridical method, which is the approach done by examining the legislation relevant to the problem under study or looking from the normative legal aspects. Technique of data collection is done by Research of Library (Library Research), that is by studying book and literature relevant with writing.
\end{abstract}

Keywords: Executive, Legislative.Relationship Partnership 


\section{PENDAHULUAN}

Secara umum dapat dikemukakan bahwa Dewan Perwakilan Rakyat Daerah (DPRD) adalah sebuah bentuk lembaga perwakilan rakyat daerah Provinsi, Kabupaten, atau Kota di Indonesia yang berkedudukan sebagai unsur penyelenggara pemerintahan daerah bersama dengan Pemerintah Daerah. Keberadaan DPRD diatur antara lain dalam Undang-Undang Nomor 27 Tahun 2009 tentang Majelis Permusyawaratan Rakyat, Dewan Perwakilan Rakyat, Dewan Perwakilan Daerah, dan Dewan Perwakilan Rakyat Daerah. Pasal 342 Undang-Undang Nomor 27 Tahun 2009 menetapkan bahwa "DPRD kabupaten/kota merupakan lembaga perwakilan rakyat daerah yang berkedudukan sebagai unsur penyelenggara pemerintahan daerah kabupaten/kota. Dalam hal ini, Josef Riwu Kaho mengemukakan bahwa "Tugas pokok kepala daerah adalah sebagai pelaksana kebijaksanaan daerah atau administrator, sedangkan tugas pokok DPRD adalah menetapkan kebijaksanaan daerah". ( Josef Riwu Kaho,2001:70)

Kedudukan DPRD ada di setiap wilayah administratif, yaitu Dewan Perwakilan Rakyat Daerah Provinsi (DPRD Provinsi), berkedudukan di ibukota Provinsi, Dewan Perwakilan Rakyat Daerah Kabupaten (DPRD kabupaten), berkedudukan di ibukota Kabupaten, dan Dewan Perwakilan Rakyat Daerah Kota (DPRD kota), berkedudukan di kota. Secara yuridis formal, DPRD merupakan mitra kerja Kepala Daerah baik Gubernur, Bupati, atau Walikota. Sejak diberlakukannya Undang Undang Nomor 32 Tahun 2004 tentang Pemerintahan Daerah, Kepala Daerah tidak lagi bertanggung jawab kepada DPRD, karena dipilih langsung oleh rakyat melalui pemilihan umum Kepala Daerah dan Wakil Kepala Daerah. Pasal 27 ayat (2) Undang Undang Nomor 32 Tahun 2004 menegaskan antara lain bahwa "Kepala Daerah mempunyai kewajiban juga untuk memberikan laporan penyelenggaraan pemerintahan daerah kepada Pemerintah, dan memberikan laporan keterangan pertanggungjawaban kepada DPRD”. Walaupun demikian, peran DPRD sangat besar dalam penentuan kebijakan daerah, seperti dikemukakan oleh Sri Djoharwinarlien (2001: 9) bahwa "Tanpa persetujuan DPRD, maka sangat sulit suatu keputusan bisa diambil".

Anggota DPRD memiliki hak interpelasi, hak angket, dan hak menyatakan pendapat. Anggota DPRD memiliki hak mengajukan rancangan peraturan daerah, mengajukan pertanyaan, menyampaikan usul dan pendapat, memilih dan dipilih, membela diri, imunitas atau hak kekebalan, mengikuti orientasi dan pendalaman tugas, protokoler, serta keuangan dan administratif. DPRD berhak meminta pejabat negara tingkat daerah, pejabat pemerintah daerah, badan hukum, atau warga masyarakat untuk memberikan keterangan. "Berhubung posisi anggota Dewan adalah menjembatani kepentingan publik, maka Dewan perlu menguasai cara untuk memainkan peran keperantaraannya" (Purwo Santoso, 2001:11).

Untuk melaksanakan tugas dan fungsinya dengan baik, DPRD memiliki alat kelengkapan yang terdiri atas Pimpinan, Badan Musyawarah, Komisi, Badan Legislasi Daerah, Badan Anggaran, Badan Kehormatan, dan alat kelengkapan lain yang diperlukan dan dibentuk oleh rapat paripurna. Selanjutnya untuk mendukung kelancaran pelaksanaan tugas DPRD, dibentuk Sekretariat yang merupakan unsur pelayanan terhadap DPRD. Untuk tingkat Kabupaten, dibentuk Sekretariat DPRD Kabupaten yang dipimpin oleh seorang Sekretaris DPRD yang diangkat oleh Kepala Daerah atas usul Pimpinan DPRD yang bertanggung jawab kepada Pimpinan DPRD dan secara administratif dibina oleh Sekretaris Daerah Kabupaten. Artinya adalah bahwa Sekretaris DPRD Kabupaten secara teknis operasional berada di bawah dan bertanggung jawab kepada Pimpinan DPRD dan secara administratif bertanggung jawab kepada Kepala Daerah melalui Sekretaris Daerah.

\section{Teori Pemisahan Kekuasaan Eksekutif dan Legislatif}

Kata eksekutif dan legislatif dipopulerkan oleh teori-teori tentang pemisahan kekuasaan negara. John Locke dan Montesquieu adalah orang yang pertama dianggap membicarakan teori ini. John Locke memisahkan kekuasaan dari tiap-tiap negara dalam: 
1. Kekuasaan legislatif, kekuasaan untuk membuat undang-undang;

2. Kekuasaan eksekutif, kekuasaan untuk melaksanakan undang-undang;

3. Kekuasaan federatif, kekuasaan mengadakan perserikatan dan aliansi serta segala tindakan dengan semua orang dan badan-badan di luar negeri (C.S.T.Kansil,1985:10).

Montesquieu mengemukakan bahwa dalam setiap pemerintahan terdapat tiga jenis kekuasaan yaitu kekuasaan legislatif, eksekutif, dan yudikatif. Ketiga kekuasaan itu harus terpisah, baik mengenai fungsi atau tugas maupun mengenai alat perlengkapan atau organ yang melaksanakan. Teori pemisahan kekuasaan negara (the separation of power) dari Montesquieu ini dikenal dengan nama trias politica, yang memisahkan kekuasaan menjadi tiga bidang. Montesquieu sebagaimana dikutip oleh Arief Budiman mengemukakan bahwa:

Kekuasaan perundang-undangan harus terletak pada badan perwakilan rakyat; kekuasaan untuk menjalankan undang-undang pada raja, kekuasaan pengadilan pada para hakim yang sama sekali bebas dari kekuasaan pelaksanaan. Ajaran yang kemudian dikenal dengan nama trias politica ini, sangat berpengaruh dalam sistem politik modern sekarang (Arief Budiman, 1996:36).

Di Indonesia, konsep trias politica sebagaimana dikemukakan oleh Montesquieu juga digunakan, akan tetapi dalam arti pembagian kekuasaan, bukan pemisahan kekuasaan. Dalam hal ini Miriam Budiardjo mengemukakan bahwa "Kekuasaan legislatif dijalankan oleh Presiden bersama-sama dengan Dewan Perwakilan Rakyat. Kekuasaan eksekutif dijalankan oleh Presiden dibantu oleh menteri-menteri, sedangkan kekuasaan yudikatif dijalankan oleh Mahkamah Agung dan lain-lain badan kehakiman" (Miriam Budiardjo, 1993 :157).

Ketiga pendapat yang telah dikemukakan dapat diketahui bahwa ada perbedaan pengertian tentang eksekutif dan legislatif. Eksekutif adalah Kepala Negara. Kepala Negara tentu tidak dapat secara sendiri menjalankan undang-undang, oleh karena itu kekuasaannya dilimpahkan (didelegasikan) kepada pejabat-pejabat pemerintah/negara yang bersama-sama merupakan suatu badan pelaksana undang-undang, yang menjalankan undang-undang dan pemerintahan, baik pada tingkat Pusat (Pemerintah Pusat) maupun di tingkat Daerah (Pemerintah Daerah). Sebagaimana halnya di Pusat, pada tingkat Daerah juga ada badan eksekutif daerah dan badan legislatif daerah. Badan eksekutif daerah adalah Kepala Daerah beserta perangkat daerah otonom yang lain yang disebut juga dengan nama Pemerintah Daerah. Sedangkan badan legislatif daerah adalah Dewan Perwakilan Rakyat Daerah (DPRD).

\section{Teori Tugas Eksekutif}

Eksekutif dalam hal ini Kepala Daerah mempunyai tugas dan kewajiban yang cukup berat, mulai dari masalah mempertahankan dan memelihara keutuhan Negara Kesatuan Republik Indonesia sampai dengan mengajukan rancangan strategis penyelenggaraan pemerintahan daerah di depan sidang paripurna DPRD. Tugas-tugas eksekutif yang diemban oleh Kepala Daerah tersebut menurut Ateng Syafrudin (1982 :14-15), dapat diklasifikasikan sebagai berikut:

1) Kepala Daerah harus dapat memecahkan berbagai masalah pemerintahan, dan dengan berbagai cara berusaha merealisasikan kebijaksanaan yang telah dianut oleh Pemerintah untuk tujuan kepentingan umum.

2) Kepala Daerah harus mempunyai kesadaran memerintah, dalam arti kata mampu melihat setiap kepentingan publik darisatu segi masalah dan mencurahkan perhatian yang besar kepada masalah itu sebagai masalah pemerintahan.

3) Kepala Daerah harus mempunyai suatu kesadaran berpolitik yang tinggi, dalam arti kata selalu membuka kemungkinan kepada masyarakat untuk menilai bahkan bila perlu mengadakan kritik atas segala tindakan yang dilakukan oleh Pemerintah, maupun menilai atau mengeritik organ-organ dan personalia yang berada di bawah pengawasannya. 
Bidang eksekutif dalam hal ini Kepala Daerah beserta perangkat daerah lainnya harus memiliki kemauan dan kemampuan di bidang pemerintahan dalam arti mau dan mampu memecahkan berbagai masalah pemerintahan, masalah kepentingan umum dan pada sisi lain juga harus memiliki kesadaran politik yang tinggi. Oleh karena itulah menurut Y.W. Sunindhia dan Ninik Widiyanti (1987:142) "Figur seorang Kepala Daerah harus mencerminkan watak daerahnya, dia harus memahami denyut nadi rakyatnya, apa yang dikehendaki mereka". Selain dari apa yang dikemukakan, maka tugas eksekutif dalam penyelenggaraan pemerintahan adalah melaksanakan keputusan legislatif dan yudikatif. Dalam hal ini, Afan Gaffar (2000:5), mengemukakan:

Tugas eksekutif dalam penyelenggaraan pemerintahan adalah "to execute" atau melaksanakan apa yang sudah disepakati atau diputuskan oleh pihak legislatif dan yudikatif. Atau juga dikatakan sebagai mengimplementasikan semua kebijaksanaan yang sudah diputuskan oleh pihak legislatif dan yudikatif. Akan tetapi karena pembuatan kebijaksanaan pemerintahan atau kebijaksanaan publik bukan semata-mata domain atau kewenangan legislatif, maka dalam sebuah pemerintahan yang modern juga tidak jarang eksekutif mengambil inisiatif sendiri di dalam mengagendakan dan merumuskan kebijaksanaan. Eksekutif di bawah pimpinan Kepala Daerah dengan demikian bertugas, berwenang dan bertanggung jawab dalam menjalankan kegiatan yang dikenal dengan nama birokrasi, dimana berbagai aspek keberhasilan pelaksanaan pemerintahan dan pembangunan daerah sangat bertumpu pada peran birokrasi itu. Dalam hal ini, Pratikno mengemukakan:

Aspek keberhasilan pembangunan dan penyelenggaraan pemerintahan sangat bertumpu kepada peran dan fungsi birokrasi. Hampir semua sektor kehidupan masyarakat telah terjamah dengan administrasi, kontrol dan dukungan birokrasi. Berbagai bentuk pelayanan publik telah melibatkan peran serta birokrasi, baik secara langsung maupun tidak langsung (Pratikno: 1997,102)

Bidang tugas eksekutif dengan demikian adalah di bidang birokrasi, yang meliputi kegiatan pelayanan, perlindungan, dan pemberdayaan masyarakat. Untuk itu dalam kerangka otonomi daerah, peran eksekutif sebagai aparat birokrasi di daerah mengemban tugas menyusun kerangka kerja yang memungkinkan terserapnya potensi dan aspirasi rakyat daerah yang dilandasi empat prinsip demokrasi. Menurut Samugyo Ibnu Redjo (2001:91-92), empat prinsip tersebut, yaitu:

1) Prinsip pemberdayaan, yang memungkinkan inisiatif dan kreativitas rakyat berkembang sehingga dapat menyalurkan potensi-potensi yang dimilikinya.

2) Prinsip pelayanan. Upaya pemberdayaan memerlukan semangat untuk melayani masyarakat (a spirit of public service) dan menjadi mitra masyarakat (partener of society); atau melakukan kerjasama dengan masyarakat (co-production).

3) Prinsip partisipasi. Melalui prinsip ini masyarakat diikutsertakan dalam proses menghasilkan public goods and service, dengan mengembangkan pola kemitraan dan kebersamaan antara birokrasi dengan rakyat.

4) Prinsip kemitraan. Peranan birokrasi pemerintah ditujukan pada arah pertumbuhan yang serasi, yaitu melalui penciptaan iklim usaha dan kondisi lingkungan bisnis yang kondusif bagi tumbuhnya kemitraan.

Bidang tugas eksekutif di daerah adalah melaksanakan tugas-tugas di bidang pemerintahan, pembangunan dan kemasyarakatan sehari-hari yang dipimpin oleh seorang kepala eksekutif daerah yaitu Kepala Daerah, dalam sebuah sistem yang dinamakan birokrasi berdasarkan kepada prinsip pemberdayaan, pelayanan, partisipasi, dan kemitraan.

\section{Teori Tugas Legislatif}

Diantara berbagai tugas legislatif, tugas yang dirasa sangat penting harus dilakukan oleh legislatif adalah melakukan kontrol atas kinerja eksekutif, yang dimaksudkan sebagai upaya 
untuk mengurangi lajunya dominasi birokrasi. Dalam hal ini, Pratikno(1997:103) mengemukakan:

Salah satu solusi utama untuk mengurangi laju dominasi birokrasi adalah efektivitas kontrol, yaitu kontrol dari lembaga legislatif serta kontrol langsung dari masyarakat terhadap birokrasi. Kontrol atau pengawasan itu pada dasarnya dilatar-belakangi oleh tujuan agar birokrasi dan para aparatnya senantiasa bisa mempertanggungjawabkan setiap tindakan yang diambil.

Melalui efektivitas kontrol tersebut, legislatif mempunyai kedudukan strategis dan disegani oleh eksekutif karena dengan tugas dan wewenang yang dimiliki itu, dapat menjatuhkan Kepala Daerah jika menurut penilaian legislatif, Kepala Daerah tidak menjalankan tugasnya secara baik dan benar sesuai dengan ketentuan yang berlaku.Oleh karenanya, keberadaan lembaga legislatif atau DPRD di daerah akan memberikan warna tersendiri terhadap jalannya pemerintahan daerah otonom, seperti dikemukakan oleh Muchlis Hamdi (2001:68) sebagai berikut:

Sebagai lembaga perwakilan rakyat di daerah, DPRD atau lembaga legislatif daerah mempunyai peranan besar dalam mewarnai jalannya pemerintahan daerah otonom. Dengan peranan yang demikian itu, aspek responsibilitas dalam pelaksanaan tugas-tugas legislatif menjadi salah satu faktorpenentu terhadap makna dan kemanfaatan pemerintahan daerah bagi terwujudnya masyarakat yang sejahtera dan berdaulat.

Pemahaman sebagaimana dikemukakan di atas memunculkan suatu kesimpulan bawa lembaga legislatif perlu terus mengembangkan dirinya yang tentu saja tidak akan terlepas dari gerak perkembangan kualitas anggota badan legislatif itu sendiri, hubungannya dengan badan eksekutif daerah, dan sebagainya. Melalui pengembangan yang demikian dapat diharapkan bahwa bidang tugas legislatif akan mampu memperlihatkan wujudnya yang jelas yang jelas yaitu sebagai wakil rakyat, pengontrol eksekutif, dan pembuat undang-undang.

\section{METODE PENELITIAN}

Penelitian ini menggunakan metode yuridis normatif, yaitu pendekatan yang dilakukan dengan cara meneliti peraturan perundang-undangan yang relevan dengan permasalahan yang diteliti atau melihat dari aspek hukum normatif. Tehnik pengumpulan data dilakukan dengan Penelitian Kepustakan (Library Research), yaitu dengan mempelajari buku dan literature yang relevan dengan penulisan.

Dalam penelitian ini jenis-jenis data dan bahan hukum yang digunakan, adalah:

1) Bahan Hukum Primer

Bahan Hukum Primer terdiri dari ketentuan peraturan perundang-undangan yang berkaitan dengan penelitian ini.

2) Bahan Hukum Sekunder

Bahan Hukum Sekunder terdiri dari buku-buku, surat kabar, majalah, jurnal, artikel.

3) Bahan Hukum Tersier

Bahan Hukum Tersier terdiri dari kamus hukum dan politik.

\section{HASIL DAN PEMBAHASAN}

\section{Hubungan Kemitraan antara Legislatif dan Eksekutif di Daerah}

Hubungan Kerjasama Legislatif dengan Pemerintah Daerah Dalam konstelasi pemerintahan di daerah, Legislatif pada hakekatnya di samping merupakan badan resmi yang mewakili rakyat, juga sebagai mitra / partner eksekutif dalam merumuskan kebijaksanaan dalam rangka menjalankan roda pemerintahan daerah, selain itu kedua lembaga itu juga mempunyai kedudukan yang sejajar. Sebagai lembaga Pemerintahan Daerah, Legislatif mempunyai kedudukan setara dan memiliki hubungan kerja bersifat kemitraan dengan Pemerintah Daerah, 
hal ini sebagai mana diatur dalam undang-undang Nomor 32 Tahun 2004. Kedudukan yang setara bermakna bahwa antara Legislatif dan Pemerintah Daerah memiliki kedudukan yang sama dan sejajar dalam arti tidak saling membawahi.

Hubungan bersifat kemitraan berarti Legislatif merupakan mitra kerja Pemerintah Daerah dalam membuat kebijakan daerah untuk melaksanakan otonomi daerah sesuai dengan tugas dan fungsi masing-masing. Berdasarkan hal tersebut antar kedua lembaga wajib memelihara dan membangun hubungan kerja yang harmonis dan satu sama lain harus saling mendukung, bukan sebagai lawan atau pesaing. Untuk terjalinnya hubungan kerja yang harmonis dan saling mendukung, diperlukan adanya pengaturan tentang hak-hak protokoler dan keuangan Pimpinan dan Anggota Legislatif. Hal tersebut bertujuan agar masing-masing memperoleh hak dan melaksanakan kewajiban meningkatkan peran dan tanggung jawab mengembangkan kehidupan demokrasi, menjamin keterwakilan rakyat dan daerah dalam melaksanakan tugas dan kewenangannya, mengembangkan hubungan dan mekanisme checks and balances antara lembaga legislatif dan eksekutif, meningkatkan kualitas, produktifitas, dan kinerja demi terwujudnya keadilan dan kesejahteraan masyarakat. Kemitraan dan kesejajaran ini selain dapat dilihat dari penelitian atau pengambilan kebijakan secara bersama-sama, juga dapat dilihat dari pengaturan akan setiap penyelenggaraan pelaksanaan acara kenegaraan atau secara resmi pengaturan akan posisi Pimpinan dan Anggota Legislatif pada setiap acara yang digelar secara resmi/formal.

Kedudukan lembaga Legislatif dengan Pemerintah Daerah adalah sejajar dan menjadi mitra dari Pemerintrah Daerah oleh sebab itu, lembaga Legislatif merupakan badan legislatif daerah yang berfungsi menetapkan tugas pemerintahan di bidang politik, sedangkan Pemerintah Daerah sebagai badan eksekutif daerah, berfungsi menyelenggarakan pelaksanaan pembangunan daerah yang telah ditetapkan oleh badan legislatif daerah. Legislatif sebagai mitra kerja eksekutif, tentu dikaitkan dengan penyelenggaraan Pemerintahan di daerah, jadi Legislatif sebagai mitra eksekutf tersebut bukanlah berarti bekerja sama untuk memenuhi kepentingan masing-masing pihak dalam arti kepentingan perseorangan, kelompok dan atau kepentingan Partai akan tetapi semata-mata antar dua lembaga tersebut dalam mengambil kebijakan-kebijakan yang telah disepakati secara bersama-sama dapat diimplemntasikan untuk kepentingan rakyat di daerah dan Negara. Serta masing-masing lembaga dalam pelaksanaan fungsinya bisa saling memahami akan tugas yang melekat pada masing-masing lembaga tersebut secara proporsional, dengan tanpa saling mencurigai, membawahi, lebih menonjolkan/mendominasi dan lain sebagainya.

Hubungan antara Eksekutif dan Legislatif secara realistis dapat dikembangkan dengan mengembangkan 3(tiga) pola hubungan yang harus Ketiga hubungan itu adalah, pertama, bentuk komunikasi dan tukar menukar informasi, Kedua, bentuk kerja sama atas beberapa subjek, program, masalah dan pengembangan regulasi, dan ketiga, klarifikasi atas berbagai permasalahan. Ketiga bentuk hubungan tersebut berbeda-beda dalam peran dan aktualisasi masing-masing pihak, baik eksekutif maupun Legislatif dan yang paling berat dirasakan kedua belah pihak mungkin dalam hubungan klarifikasi. Namun, kolaborasi tersebut hanya mungkin menjadi kenyataan jika dikembangkan etika yang dapat merefleksikan bahwa Legislatif bukan sebagai ancaman tetapi lembaga yang bekerja untuk kepentingan masyarakat. Sebaliknya Pemerintah Daerah diharapkan mampu menciptakan suasana kondusif. yang dapat mendorong Legislatif bekerja secara independent dan tetap kritis. Pada prinsipnya urgensi jenis hubungan antara eksekutif dan legislatif tersebut meliputi hal-hal, yaitu : representasi, anggaran, pertanggungjawaban, pembuatan peraturan daerah, pengangkatan sekretaris daerah, pembinaan dan pengawasan. Kesemua hal tersebut dapat terwujud, dan berjalan sebagaimana diharapkan bilamana baik eksekutif maupun legislatif memiliki visi bersama yaitu suatu visi yang bukan saja menyangkut kelembagaan, tetapi juga secara individual mereka merasa benar-benar terikat (committee), karena hal tersebut mencerminkan visi pribadi masing-masing. 
Harmonisasi hubungan antara eksekutif dan Legislatif dalam kontek tata laksana penyelenggaraan pemerintahan di daerah sedikit banyak ikut menentukan terciptanya situasi yang kondusif bagi keberhasilan program-program pembangunan daerah. Karena itu pola hubungan yang seimbang dan egaliter antara dua lembaga tersebut perlu terus menerus ditingkatkan sebagai upaya menjaga stabilitas politik di daerah. Dengan demikian, dalam beberapa kasus kerap terjadi disharmonisasi hubungan antara eksekutif dan Legislatif, baik dalam konteks kesalahpahaman dalam menerjemahkan makna substansi undang-undang, maupun lebih bersifat politik. Bahkan fluktuasi hubungan antara kedua lembaga tersebut tidak mustahil mengarah pada terjadinya konflik politik. Hal ini bisa terjadi dalam dua hal, pihak eksekutif yang belum sepenunhnya memahami ataukah pihak legislatif yang kerap mengarah pada perilaku "politicking". Jika hal ini terjadi pada level legislatif atau anggota-anggota Legislatif, maka sudah seharusnya dan sepantasnyalah jajaran Legislatif untuk menginstrospeksi dan melihat kedepan terhadap substansi persoalan, bukan malah mempolitisasi sehingga permasalahan yang begitu prinsipil hanya dijadikan sebagai komoditas politik.

Pemerintahan Daerah menurut Undang-Undang Nomor 32 Tahun 2004, telah mengalami perubahan yang cukup signifikan dibandingkan dengan Pemerintah Daerah di era Undangundang Nomor 22 Tahun 1999. Pemerintah Daerah menurut Undang-Undang Nomor 22 Tahun 1999 adalah Kepala Daerah dan Legislatif. Kepala Daerah berkedudukan sebagai Lembaga Eksekutif Daerah, sedangkan Legislatif berkedudukan sebagai Lembaga Legislatif Daerah. Disini tergambar adanya checks and balances dalam pemerintahan (terlepas dan implementasinya banyak menimbulkan persoalan). Sedangkan menurut Undang-undang Nomor 32 Tahun 2004 pada pasal 1 ayat (3), Pemerintah Daerah adalah gubernur, bupati, atau walikota dan perangkat daerah. Sedangkan Legislatif dirumuskan sebagai unsur penyelenggaraan Pemerintahan daerah.

Sebagai lembaga Pemerintahan Daerah, Legislatif mempunyai kedudukan setara dan memiliki hubungan kerja bersifat kemitraan dengan Pemerintah Daerah. Kedudukan yang setara berrnakna bahwa antara Legislatif dan Pemerintah Daerah merniliki kedudukan yang sama dan sejajar dalam arti tidak saling membawahi. Hubungan bersifat kemitraan berarti Legislatif merupakan mitra kerja Pemerintah Daerah dalam membuat kebijakan daerah untuk melaksanakan otonomi daerah sesuai dengan tugas dan fungsi masing-masing. Berdasarkan hal tersebut antar kedua lembaga wajib memelihara dan membangun hubungan kerja yang harmonis dan satu sama lain harus saling mendukung, bukan sebagai lawan atau pesaing.Untuk terjalinnya hubungan kerja yang harmonis dan saling mendukung, diperlukan adanya pengaturan tentang hak-hak protokoler dan keuangan Pimpinan dan Anggota Legislatif.

Hal tersebut bertujuan agar masing-masing memperoleh hak dan melaksanakan kewajiban meningkatkan peran dan tanggung jawab mengembangkan kehidupan demokrasi, menjamin keterwakilan rakyat dan daerah dalam melaksanakan tugas dan kewenangannya, mengembangkan hubungan dan mekanisme check and balance antara lembaga eksekutif dengan lembaga legislatif, meningkatkan kualitas, produktifitas, dan kinerja demi terwujudnya keadilan dan kesejahteraan masyarakat. Pengaturan tentang kedudukan protoler Pimpinan dan Anggota merupakan pedoman pelaksanaan acara kenegaraan atau secara resmi Pemerintahyang diselenggarakan di daerah sehubungan dengan jabatannya sebagai Pimpinan dan anggota Legislatif. Pengaturan dimaksud meliputi pengaturan tata tempat, tatau pacara, dan tata penghormatan. Hubungan antara Legislatif Daerah dan Eksekutif Daerah (Kepala Daerah dan perangkatnya) sebagaimana diatur dalam UU No. 32 tahun 2004 di dalam pasal 16 ayat (2) UU No. 32 tahun 2004 tentang Pemerintahan Daerah, dijelaskan secara lengkap bahwa: "Legislatif sebagai badan legislatif daerah berkedudukan sejajar dan menjadi mitra dari pemerintah daerah". Berdasarkan isi pasal tersebut dapat diambil gambaran bahwa Legislatif merupakan mitra sejajar eksekutif. Isi pasal 16 ayat (2) tersebut bertentangan dengan isi pasal 44 ayat (2), yang isinya: "Dalam menjalankan tugas dan kewajiban kepala daerah bertanggung jawab 
kepada Legislatif'. Konsep laporan pertanggungjawaban, mempunyai dua subjek yang berbeda tingkatan. Subjek yang meminta pertanggungjawaban, mempunyai posisi yang lebih tinggi jika dibandingkan dengan subjek yang dimintai pertanggungjawaban.

Letak kesejajaran antara Legislatif sebagai legislatif daerah dan Pemerintah Daerah sebagai eksekutif daerah, ada dua alasan. Pertama, bermitra di satu sisi dan laporan pertanggungjawaban di sisi yang lain terjadi karena legislatif secara fungsi merupakan gabungan antara DPR dan MPR (ditingkat pusat) sedangkan di daerah hanya dilaksanakan oleh satu lembaga yaitu Legislatif. Kedua, Legislatif bermitra dengan eksekutif ketika menjalankan legislative and budgetting functions, sedangkan laporan pertanggungjawaban merupakan pengejewantahan control functions. Anggota LEGISLATIF mungkin akan lebih berminat menilai Laporan Pertanggungjawaban Bupati (LPJ), ketimbang menjalankan fungsinya yang lain, yaitu fungsi legislasi dan anggaran. Jika seandainya sistem pemerintahan daerah kita mau menganut check and balances system, maka kondisi tersebut tidak terlihat dalam UU No. 32 tahun 2004 tentang Pemerintahan Daerah. Pola kemitraan pada dasarnya biasa dikenal dalam dunia ekonomi, kemitraan dilaksakan untuk meningkatkan kesejahteraan diantara yang bermitra, atau dengan kata lain tujuan yang diinginkan dapat dicapai dengan maksimal oleh mitra-mitra

Hubungan yang terjadi antara legislatif dan Kepala Daerah adalah hubungan politik, karena keduanya merupakan organ politik, sehingga apabila pola kemitraan yang terlalu dikedepankan, maka hanya akan membentuk "koncoisme" antara legislatif dan Pemerintah Daerah. Hal tersebut berarti akan berimbas terhadap proses akuntabilitas pelaksanaan pemerintahan.

\section{Hubungan Kemitraan antara eksekutif dan legislatif dalam Proses Penyusunan Ranperda}

Menurut Undang- Undang Nomor 10 Tahun 2004 tentang Pembentukan Peraturan Perundang-undangan yang dimaksud dengan Peraturan Daerah (Perda) adalah peraturan perundang-undangan yang dibentuk oleh Dewan Perwakilan Rakyat Daerah dengan persetujuan bersama Kepala Daerah. Definisi lain adalah peraturan perundang- undangan yang dibentuk bersama oleh Dewan Perwakilan Rakyat Daerah dengan Kepala Daerah baik di Propinsi maupun di Kabupaten/Kota. Dalam Undang-Undang Nomor 32 Tahun 2004 tentang Pemerintahan Daerah (UU Pemda), Perda dibentuk dalam rangka penyelenggaraan otonomi daerah Propinsi/Kabupaten/Kota dan tugas pembantuan serta merupakan penjabaran lebih lanjut dari peraturan perundang-undangan yang lebih tinggi dengan memperhatikan ciri khas masingmasing daerah.

Dalam UU no 12 tahun 2011 tentang Pembentukan Peraturan Perundang-undangan, Perda adalah seluruh materi muatan dalam rangka penyelenggaraan otonomi daerah dan tugas pembantuan dan menampung kondisi khusus daerah serta penjabaran lebih lanjut Peraturan Perundang-undangan yang lebih tinggi. Rancangan Peraturan Daerah dapat berasal dari Dewan Perwakilan Rakyat Daerah (Legislatif), Gubernur atau Bupati/Walikota. Apabila dalam satu kali masa sidang Gubernur atau Bupati/Walikota dan Legislatif menyampaikan rancangan Perda dengan materi yang sama, maka yang dibahas adalah rancangan Perda yang disampaikan oleh legislatif, sedangkan rancangan Perda yang disampaikan oleh Gubernur atau Bupati/Walikota dipergunakan sebagai bahan persandingan. Program penyusunan Perda dilakukan dalam satu Program Legislasi Daerah 4, sehingga diharapkan tidak terjadi tumpang tindih dalam penyiapan satu materi Perda. Ada berbagai jenis Perda yang ditetapkan oleh Pemerintah Daerah Kabupaten Kota dan Propinsi antara lain:
a. Pajak Daerah;
b. Retribusi Daerah;
c. Tata Ruang Wilayah Daerah;
d. APBD; 
e. Rencana Program Jangka

f. Menengah Daerah;

g. Perangkat Daerah;

h. Pemerintahan Desa;

i. Pengaturan umum lainnya.

Peraturan daerah yang kita kenal dengan istilah perda merupakan suatu produk hukum yang dibuat oleh perangkat pemerintah daerah guna mengatasi suatu permasalahn yang muncul. Dibuat atau disusunnya suatu peratuaran daerah sampai dengan diterapkannya tentu perlu proses yang panjang. Disamping proses yang panjang perlu juga yang namanya kerjasama yang baik, dimana kerjasama yang baik yangg dimaksud adalah bagaimana semua stakeholder yang terkait mampu bekerjasama untuk membuat sampai dengan diterapkannya peraturan daerah yang dimaksud.

Dalam penyampaian usulan rancangan peraturan daerah ada dua macam bentuk pengusulan yaitu secara inisiasi legislatif atau secara inisiatif Pemerintah daerah yang dimotori oleh Kepala Derah baik itu Bupati maupun Walikota. Namun, sejalan dengan itu semua baik itu rancangan peraturan daerah yang berasal dari anggota legislatif maupun yang berasal dari pemerintah daerah yang disampaikan oleh Kepala Daerah itu semuanya diselesaikan bersamasama, semuanya saling terlibat satu sama lainnya. Penyusunan Prolegda dilaksanakan oleh pemerintah daerah dan legislatif. Disusun berdasarkan atas:

(a) perintah peraturan perundang-undangan lebih tinggi;

(b) rencana pembangunan daerah;

(c) penyelenggaraan otonomi daerah dan tugas pembantuan; dan

(d) aspirasi masyarakat daerah.

Rancangan Perda yang berasal dari Legislatif atau kepala daerah dibahas oleh legislatif dan kepala daerah untuk mendapatkan persetujuan bersama. Pembahasan dilakukan melalui 2 (dua) tingkat pembicaraan, yaitu pembicaraan tingkat I dan pembicaraan tingkat II. Pembicaraan tingkat I Dalam hal Rancangan Perda berasal dari kepala daerah dilakukan dengan: penjelasan kepala daerah dalam rapat paripurna mengenai Rancangan Perda; pemandangan umum fraksi terhadap Rancangan Perda; dan tanggapan dan/atau jawaban kepala daerah terhadap pemandangan umum fraksi. Pembicaraan tingkat II meliputi: (a) pengambilan keputusan dalam rapat paripurna yang didahului dengan: penyampaian laporan pimpinan komisi/pimpinan gabungan komisi/pimpinan panitia khusus yang berisi pendapat fraksi dan hasil pembahasan sebagaimana dimaksud dalam Pasal 35 huruf; dan permintaan persetujuan dari anggota secara lisan oleh pimpinan rapat paripurna. (b) pendapat akhir kepala daerah.

Dalam proses penyusunan rancangan peraturan daerah sampai dengan disahkannya peraturan daerah yang telah disusun tersebut, baik ranperda yang diusulkan oleh anggota Legislatif itu sendiri maupun yang diusulkan oleh pemerintah daerah melalui Kepala Daerah semuanya itu melalui proses yang panjang dalam proses legislasi. Didalamnya itu pemerintah daerah baik itu Bupati atau Walikota saling terkait satu sama lain dengan pihak Legislatif.

Usulan Ranperda dapat diinisiasi oleh Pemda dan Legislatif dengan aturan main yang berbeda. Berdasarkan PP No. 1 Tahun 2001, Penyusunan Ranperda hasil usulan Legislatif diawali oleh pengajuan usulan oleh sejumlah anggota yang terdiri atas lebih dari satu fraksi. Usulan tersebut disampaikan secara tertulis kepada pimpinan Legislatif dalam bentuk Ranperda, disertai penjelasannya. Usul tersebut kemudian diberi nomor pokok oleh sekretariat Legislatif. Setelah itu disampaikan oleh pimpinan Legislatif pada rapat paripurna setelah terlebih dahulu mendapat pertimbangan dari panitia musyawarah (pamus). Sedangkan penyusunan Ranperda hasil usulan pemda, menurut Kepmendagri No. 23 Tahun 2001, unit kerja dan pimpinan dinas/lembaga teknis daerah dapat mengambil prakarsa untuk menyusun Ranperda. Usulan Ranperda tersebut dimintakan persetujuannya kepada kepala daerah melalui sekretaris daerah. Sebelum diajukan kepada kepala daerah, sekretaris daerah melalui bagian hukum bisa 
melakukan harmonisasi dan sinkronisasi. Permohonan persetujuan dilampiri dengan pokokpokok pikiran atau konsepsi pengaturan, yang memuat: (1) latar belakang, maksud dan tujuan pengaturan; (2) dasar hukum; (3) materi yang diatur, dan (4) keterkaitan dengan peraturan perundang-undangan lain.

\section{SIMPULAN}

Pertama, Peranan Pemerintah Daerah dan Legislatif Daerah sangat diperlukan untuk mengemban pelaksanaan prinsip pembagian kekuasaan di daerah. Pemerintah Daerah adalah eksekutif sedangkan legislatif daerah merupakan representasi rakyat di suatu daerah otonom. Untuk itu dalam hubungan kemitraan keduanya, dapat saja timbul berbagai pola hubungan yang melahirkan suatu dinamika. Kedua, Hubungan yang dijalin antara Kepala Daerah baik itu Bupati atau Walikota dengan Legislatif Kabupaten atau Kota dengan Legislatif Kabupaten Kota dalam proses penyusunan rancangan peraturan deerah itu merupakan salah satu bentuk dari penciptaan suasana good governance pada tataran pemerintahan daerah, baik pemerintah daerah maupun Legislatif harus bersinergi di dalam menciptakan suasana pemerintahan yang baik. Dimana dalam penyusunan rancangan peraturan daerah tidak boleh ada nuansa menjatukan satu sama lain meskipun meskipun ada perbedaan pandangan dari berbagai fraksi.

\section{REFERENSI}

Buku

Affan Gaffar. 2000. Tugas dan Kekuasaan Eksekutif, dalam Afan Gaffar dkk, Hubungan Eksekutif dan Legislatif di Daerah. Universitas Gadjah Mada, Yogyakarta.

Arief Budiman. 1996. Teori Negara, Negara Kekuasaan dan Ideologi. Gramedia Pustaka Utama. Jakarta.

Ateng Syafrudin.1982. Hubungan Kepala Daerah Dengan Dewan Perwakilan Rakyat Daerah. Tarsito. Bandung.

Bambang Yudoyono. Otonomi Daerah Desentralisasi dan Pengembangan SDM Aparatur Pemda dan Anggota DPRD. Sinar Harapan, Jakarta.

Bambang Purwoko. 2000. Membangun Kemitraan Strategis: Posisi DPRD di tengah Arus Perubahan, dalam Afan Gaffar dkk. Hubungan Eksekutif dan Legislatif di Daerah. Fisipol Universitas Gadjah Mada. Yogyakarta.

Josef Riwu Kaho, 2000.Prospek Otonomi Daerah di Negara Republik Indonesia, RajaGrafindo Persada, Jakarta.

Kansil, C.S.T. 1985. Sistem Pemerintahan Indonesia. Aksara Baru. Jakarta.

Miriam Budiardjo. 1993. Dasar-dasar Ilmu Politik. Gramedia Pustaka Utama. Jakarta.

Muchlis Hamdi. Peranan dan Kapabilitas Lembaga Legislatif Pada Pelaksanaan Program Pembangunan Daerah Otonom. dalam Andi A. Malarangeng dkk. 2001.Otonomi Daerah Perspektif Teoritis dan Praktis. Bigraf Publishing. Yogyakarta.

Pratikno, Birokrasi Indonesia, dalam Bey Suryawikarta dkk, 1997.Birokrasi di Indonesia, Departemen Dalam Negeri, Jakarta.

Samugyo Ibnu Redjo, Reposisi Birokrasi dalam Pelaksanaan Otonomi Daerah: Demokrasi Sebagai Model. dalam Andi A. Malarangeng dkk, 2001.Otonomi Daerah Perspektif Teoritis dan Praktis.Bigraf Publishing. Yogyakarta.

Sunindhia, Y.W. dan Ninik Widiyanti. 1987. Praktek Penyelenggaraan Pemerintahan di Daera., Bina Aksara. Jakarta.

Sri Djoharwinarlien, 2001.Penyerapan Aspirasi Masyarakat dalam Penyusunan Peraturan Daerah, dalam Afan Gaffar dkk. Hubungan Eksekutif dan Legislatif di Daerah. Universitas Gadjah Mada. Yogyakarta. 


\section{Perundang-Undangan}

Undang-undang Nomor 12 tahun 2011 tentang Pembentukan Peraturan Perundang-undangan Undang-undang Nomor 32 Tahun 2004 tentang Pemerintahan Daerah.

Undang-undang Nomor 11 Tahun 2006 tentang Pemerintahan Aceh.

Undang-Undang Nomor 27 Tahun 2009 tentang Majelis Permusyawaratan Rakyat, Dewan Perwakilan Rakyat, Dewan Perwakilan Daerah, dan Dewan Perwakilan Rakyat Daerah.

Peraturan Pemerintah Nomor 1 Tahun 2001 tentang Pedoman Penyusunan Tata Tertib Dewan Perwakilan Rakyat Daerah

Keputusan Mentri Dalam Negeri Nomor 23 Tahun 2001 tentang Prosedur Penyusunan Produk Hukum Daerah. 